\title{
Survival of mite infested (Varroa destructor) honey bee (Apis mellifera) colonies in a Nordic climate*
}

\author{
Ingemar FRIES ${ }^{\mathrm{a}}$, Anton IMDORF ${ }^{\mathrm{b}}$, Peter ROSENKRANZ \\ ${ }^{a}$ Department of Entomology, Swedish University of Agricultural Sciences, Box 7044, 75007 Uppsala, Sweden \\ ${ }^{\mathrm{b}}$ Swiss Apicultural Institute, FAM, Liebefeld, 3003 Bern, Switzerland \\ ${ }^{c}$ State Institute of Apiculture, University of Hohenheim, 70593 Stuttgart, Germany
}

Received 7 November 2005 - Accepted 23 December 2005

\begin{abstract}
An isolated honey bee population ( $\mathrm{N}=150)$ was established on the southern tip of Gotland, an island in the Baltic sea. After infestation with 36 to 89 Varroa destructor mites per colony, they were unmanaged and allowed to swarm. For over six years colonies were monitored for swarming, winter losses, infestation rate in the fall, and bee population size in the spring. Winter mortality rate decreased from $76 \%$ and $57 \%$ in the third and fourth years, to $13 \%$ and $19 \%$ in the fifth and sixth years. Swarming rates increased from zero the third field season to $57.1 \%$ and $36.4 \%$ in the last two years. The mite infestation on adult bees decreased during the last two years, from $0.47 \%$ in the third year to $0.19 \%$ and $0.22 \%$ respectively. Our data suggest that a host-parasite co-adaptation has occurred ensuring survival of both the host and the parasite. The mechanisms behind this co-adaptation require further study.
\end{abstract}

Varroa destructor / Apis mellifera / host-parasite interaction / survival / adaption

\section{INTRODUCTION}

Varroa destructor Anderson and Trueman mites have become a major plague for world beekeeping of European bees (Apis mellifera L.), although the impact from mite infestations varies greatly between continents (Rosenkranz, 1999). The original host of the mite $V$. destructor, the Asian honey bee Apis cerana Fabr., is not damaged to any appreciable degree by the infestations mainly because mite reproduction occurs only in drone brood, and mites become increasingly entrapped in dying drone brood when the mite population increases (Rath and Drescher, 1990). Grooming of mites is also more effective in A. cerana, compared to A. mellifera (Peng et al., 1987), but the impact from this behaviour on mite tolerance probably has been over emphasized (Fries et al., 1996).

Corresponding author: I. Fries, ingemar.fries@entom.slu.se

* Manuscript editor: Stefan Fuchs
It is well documented that Africanized honey bees (Apis mellifera adansoni imported into Brazil) also survive and coexist with $V$. destructor in South America (Rosenkranz, 1999) and similar host-parasite adaptations have also been reported from North Africa (Boecking and Ritter, 1993). In Europe, however, it is generally accepted that the mite population must be controlled to avoid colony collapse (Fries et al., 1994). Nevertheless, although data demonstrate that in a Nordic climate colonies infested by $V$. destructor are damaged and are likely to die over winter only three years post infestation (Korpela et al., 1993), there are frequent anecdotal reports in beekeeping journals of mite infested colonies surviving extended periods without mite control. Although such claims are often difficult to verify, a documented case of European honey bees surviving mite infestation without treatment is found on an island $345 \mathrm{~km}$ off the coast of Brazil (de Jong and Soares, 1997). Italian bees infested with $V$. destructor were 
introduced in 1984 onto this island and this bee population later increased in size without mite control (de Jong and Soares, 1997). Recently, the return of feral bee populations has been reported from France (Le Conte, 2004) and the USA (Seeley, 2004), indicating long-term survival of non-treated mite infested honey bee colonies in Europe as well as in the US. In France there are also reports of mite tolerant bees developing based on bee material brought into Europe from Tunesia (Kefuss et al., 2004). It remains unknown if this development occurs because of increased mite tolerance in the host, reduced virulence in the parasite (with the virus infections vectored), or both.

Epidemiological considerations predict that honey bees and $V$. destructor may develop a benign host-parasite relationship, but this depends on beekeepers maintaining selection pressure on both the bees and mites imposed by the infestations. This means that beekeepers should not constantly remove mites from the system through mite control methods (Fries and Camazine, 2001). Host-parasite adaptations have probably occurred where mites and bees coexist, although these processes have not been documented. On the other hand, the introduction of an exotic parasite, $V$. destructor, into a new host system, A. mellifera, could potentially lead to local eradication of the honey bee species. The invasion of an exotic species into an ecosystem is currently viewed as one of the most important sources of biodiversity loss and may lead to host eradication (Deredec and Courchamp, 2003).

We have studied the survival rate for over six years in a population of $V$. destructor infested honey bee colonies in an isolated area to determine if all colonies would perish, and their parasites along with them.

\section{MATERIALS AND METHODS}

In 1999 we established a genetically diverse honey bee population of 150 honey bee colonies in 8 apiaries with variable distances between apiaries (500 $\mathrm{m}$ to $2 \mathrm{~km}$ ). The apiaries ( $\mathrm{N} 58^{\circ} 01^{\prime}-\mathrm{N} 58^{\circ} 04^{\prime}$, E $18^{\circ} 09^{\prime}-\mathrm{E} 18^{\circ} 15^{\prime}$, only a few meters above sea level) were located on "Sudret", which is the southern tip of the island Gotland in the Baltic sea, isolated from the main island through a narrow land bridge. In July of the same year, these mite free colonies were infested with 36 to $89 \mathrm{~V}$. destructor by adding $400 \mathrm{~cm}^{3}$ of bees (number of mites calculated from three separate sub-samples), collected from mite infested colonies. No mite treatments were performed at all and the colonies were allowed to swarm at will. The only management of experimental colonies throughout the six year monitoring period consisted of data sampling and of feeding of sugar solution for winter in cases where honey stores were deemed insufficient for winter survival. The hives used were Swedish standard hives with a frame size of $366 \times 222 \mathrm{~mm}$. Throughout the experiment each colony has had access to two boxes with a total of 20 combs. The background and the origin of the bees and the impact from swarming on mite population dynamics have been described in some detail (Fries et al., 2003).

\subsection{Data collection and analysis}

Inspections of all colonies were done 4 times each year during the summers of 2000-2005 to register if colonies had swarmed or not. When colonies had emerged queen cells and a break in brood production, they were registered as swarming colonies. Swarms were collected on site upon inspection or from swarm boxes put up in the experimental area. In one colony with mature queen cells in 2003, an artificial swarm was produced to avoid losing this swarm. In 2004 and in 2005 four artificial swarms each year were made the same way following swarm preparations in individual colonies. In 2004, one natural secondary swarm was also captured. Swarms collected or produced were placed in separate apiaries each year but returned to the apiary where they originated the following year.

Late October 2000-2005, when colonies have no sealed brood in the study region, samples of approximately $100 \mathrm{~cm}^{3}$ of bees were taken from all colonies to measure mite infestation levels. Colonies that were wintered each year were regarded as surviving the winter if they had a queen and enough bees (i.e. more than 1000 bees) to expand in June the following year.

During the first inspection (late April or early May) each year, the size of the bee population in each colony was investigated from 2001 through 2005 by examining the combs and estimating the number of bees on each comb (Imdorf et al., 1987). Throughout the experiment, no attempt was made to strengthen any colony by adding bees, or to replace failing queens. Thus, a few colonies were lost 


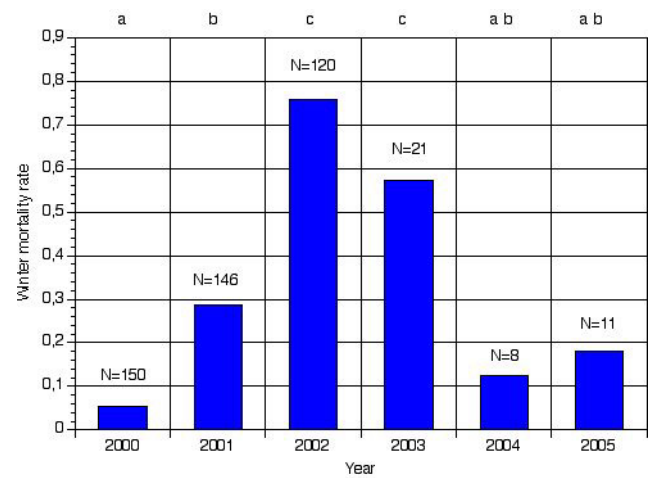

Figure 1. Mortality rate of honey bee colonies over six winters without control of Varroa destructor. $\mathrm{N}=$ number of colonies in late October each year. Bars with different letters above are significantly different between years $(P<0.05$, chi-square)

during the breeding season not due to colony collapse, but to queens becoming drone layers. This explains why some colonies disappeared from the experiment for reasons other than winter mortality.

The proportion of colonies that died each winter and the swarming rate of colonies each field season were compared between years using chi-square statistics. The mite load of colonies in late fall was compared using a Kruskall-Wallis test for mite infestation rate, with year as grouping variable. The data for each year were also analyzed by correlating first the mite infestation in the fall with the bee population size in the spring (between years, over winter) and second the bee population in the spring with the mite population in the fall (within year, over summer). The influence of the mite infestation level on bee population size in the spring and the influence of the bee population size in the spring on the mite infestation level in the fall were also analyzed (ANOVA) where the influence of year was added to the respective models.

\section{RESULTS}

\subsection{Winter mortality, swarming and mite infestation rate}

Figure 1 shows the mortality rates of wintered colonies each year of the experiment. The mortality rate during winter decreased after the third year of the experiment when more than $80 \%$ of the wintered colonies died. The

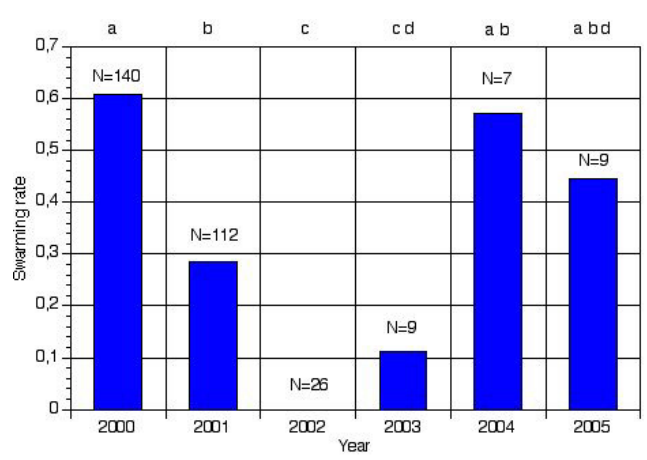

Figure 2. Swarming rate of honey bee colonies for six years without $V$. destructor control. $\mathrm{N}=$ number of colonies in late May each year. Bars with different letters above are significantly different between years $(P<0.05$, chi-square).

mortality rates during the two last years of the experiment were not significantly different from the first winter with low mite infestation levels $(P>0.05$, chi-square), whereas the mortality rates the last two winters were significantly lower compared to the two preceding years $(P<0.05$, chi-square). The swarming rate of colonies throughout the experiment showed the opposite trend compared to the mortality rate (Fig. 2). During the third year, no colony showed any swarming tendency, whereas the swarming frequency increased significantly in the last years of the experiment (Fig. 2) $(P<0.05$, chi-square) The mite infestation levels on adult bees in the fall in broodless colonies are graphed in Figure 3. The average infestation levels were significantly reduced by about $50 \%$ during the sixth and seventh fall recordings from high infestation rates of 40 or more mites per 100 bees during the second to the fourth fall of the experiment $(P<0.05$, Kruskall-Wallis $)$.

Table I lists the number of colonies and swarms that survived throughout the experiment. The survival of swarms did not seem to be better compared to the "mother" colonies (here called "original colony"), which remained in the apiary with the new queen. This finding is congruent with earlier evaluations from the same experiment (Fries et al., 2003). 
Table I. Number of wintered and surviving original colonies and swarms respectively and total number or colonies in the experiment.

\begin{tabular}{ccccccccc}
\hline Year & Parameter & $\begin{array}{c}\text { Original } \\
\text { colonies }\end{array}$ & $\begin{array}{c}\text { Swarms } \\
2000\end{array}$ & $\begin{array}{c}\text { Swarms } \\
2001\end{array}$ & $\begin{array}{c}\text { Swarms } \\
2003\end{array}$ & $\begin{array}{c}\text { Swarms } \\
2004\end{array}$ & $\begin{array}{c}\text { Swarms } \\
2005\end{array}$ & $\begin{array}{c}\text { Total, no of } \\
\text { colonies }\end{array}$ \\
\hline 1999 & Wintered & 150 & - & - & - & - & - & 150 \\
2000 & Survived & 142 & - & - & - & - & - & 142 \\
2000 & Wintered & 130 & 16 & - & - & - & - & 146 \\
2001 & Survived & 92 & 12 & - & - & - & - & 104 \\
2001 & Wintered & 91 & 12 & 17 & - & - & - & 120 \\
2002 & Survived & 21 & 8 & 0 & - & - & - & 29 \\
2002 & Wintered & 17 & 4 & 0 & - & - & - & 21 \\
2003 & Survived & 9 & 0 & 0 & - & - & - & 9 \\
2003 & Wintered & 8 & 0 & 0 & 1 & - & - & 8 \\
2004 & Survived & 6 & 0 & 0 & 1 & - & - & 7 \\
2004 & Wintered & 6 & 0 & 0 & 1 & 4 & - & 11 \\
2005 & Survived & 5 & 0 & 0 & 1 & 3 & - & 9 \\
2005 & Wintered & 5 & 0 & 0 & 1 & 3 & 4 & 13 \\
\hline
\end{tabular}

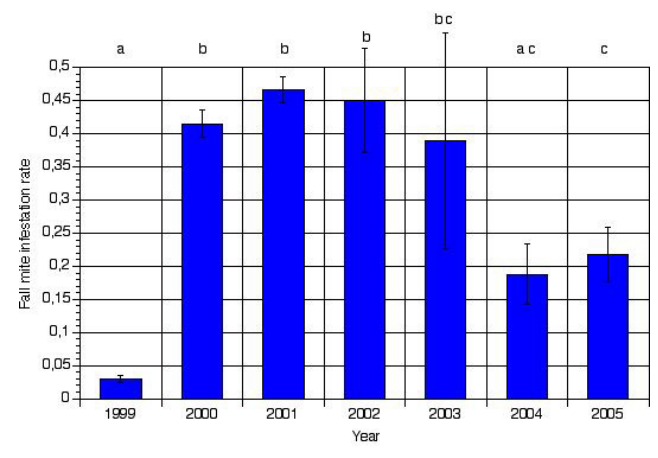

Figure 3. Average infestation rate of adult bees in brood-less colonies in late October each year. $\mathrm{N}=$ number of colonies in late October sampled each year. Bars with different letters above are significantly different between years $(P<0.05$, KruskallWallis).

\subsection{Mite infestation in the fall vs. bee population the following spring}

There was a significant negative correlation between the mite infestation rate in the fall and the size of the bee population in the spring for each winter even when colonies that died over winter were removed from the data set (Tab. II). When data from all the years were combined this negative relationship remained $(-0.31, P<0.001)$. An analysis of variance (data not shown), with bee population size in the spring as the dependent variable and
Table II. Correlation coefficients between mite infestations in the fall and bee population size in the spring $(\log 10)$ the following year in surviving colonies. Values are given for each year separately and for the combined data set.

\begin{tabular}{lccc}
\hline Winter & Correlation coefficient & $\mathrm{N}$ & $P$-value \\
\hline $1999 / 2000$ & -0.20 & 15 & 0.49 \\
$2000 / 2001$ & -0.42 & 121 & $<0.001$ \\
$2001 / 2002$ & -0.12 & 36 & 0.50 \\
$2002 / 2003$ & -0.33 & 11 & 0.33 \\
$2003 / 2004$ & -0.46 & 7 & 0.32 \\
$2004 / 2005$ & -0.77 & 9 & 0.013 \\
$1999-2005$ & -0.33 & 199 & $<0.001$ \\
\hline
\end{tabular}

mite infestation rate during fall (not including the first winter when mite levels were low (Fig. 1)) and year as independent variables, demonstrated that both parameters had a significant influence $(P<0.0001)$ on the variation in bee population size in the spring.

\subsection{Bee population in the spring vs. mite infestation the same fall}

For the two years with the largest number of observations (2001 and 2002) and for the fifth year there was a significant positive correlation between the bee population size in the spring and the mite infestation rate during the same fall, (Tab. III). When data from all the years were combined there was a significant positive 
Table III. Correlation coefficients between bee population size in the spring $(\log 10)$ and mite infestations in the fall the fall of the same year. Values are given for each year separately and for the combined data set.

\begin{tabular}{lccc}
\hline Summer & Correlation coefficient & $\mathrm{N}$ & $P$-value \\
\hline 2000 & 0.44 & 14 & 0.12 \\
2001 & 0.27 & 103 & 0.006 \\
2002 & 0.54 & 21 & 0.01 \\
2003 & -0.18 & 7 & 0.71 \\
2004 & 0.87 & 7 & 0.008 \\
2005 & -0.08 & 9 & 0.84 \\
$2000-2005$ & 0.27 & 161 & 0.0004 \\
\hline
\end{tabular}

correlation $(0.27, P<0.001)$. An analysis of variance (data not shown), with the fall mite infestation rate as the dependent variable and the bee population size in the spring and year as independent variables, demonstrated only a tendency $(P=0.12)$ of a direct influence from the bee population size on the variation in fall mite infestation rates.

\section{DISCUSSION}

This is the first experimental data from Europe with continuous monitoring where it is demonstrated that honey bee colonies infested by $V$. destructor may survive for over 6 years even if mite control is not practiced. The presented data suggest that some form of adaptation has occurred in the system, ensuring the survival of both the host and the parasite. The fact that (i) the proportion of colonies that died over winter decreased significantly (Fig. 1), (ii) the swarming incidence increased (Fig. 2), and (iii) the mite infestation rate of adult bees in the fall decreased significantly (Fig. 3) strongly supports the hypothesis that the system will develop a host-parasite relationship where both parties will survive even if mite control is not practiced. This is what could be predicted from an evolutionary epidemiological perspective (Fries and Camazine, 2001) provided the host population does not perish. Whether this persistent relationship is dependent on the bees becoming mite tolerant, the mites (and vectored virus infections) becoming less virulent, or both, remain to be investigated.
Our experiment demonstrated that most colonies were likely to succumb within the first three years if left untreated, which was expected from previous experience. During this phase of selection a fluctuating population size of the honey bee colonies, induced by the mite parasitism, may have supported the survival of some colonies even without changes in host resistance or parasite virulence. Such a pattern became clear when the interactions between the host and the parasite were considered. First it was obvious that there was a significant negative correlation between the mite infestation rate in the fall and the number of bees in the following spring (except for the first year when no effect was expected because the mite population was still low). This observation was supported by the results from an analysis of variance where both the influence from winter and mite infestation level in the fall had a significant impact on the spring population size of the bees. This means that the mite infestation level in the fall was decisive for how well the colonies survived the winter, something previously demonstrated in an earlier phase of this experiment (Fries et al., 2003). Likewise, the bee population size in the spring seemed to influence the mite infestation rate in the fall (Tab. III) with a positive correlation for most part of the data set. An analysis of variance, however, demonstrated no significant tendency $(P=0.12)$ of a direct influence from the bee population size on the variation in fall mite infestation rates.

Thus, the data confirm that heavy mite infestation levels in the fall led to poor wintering survival. Those colonies that nevertheless did survive with small number of bees also had small absolute numbers of mites because mites and bees had similar death rates in over-wintering colonies (Fries and PerezEscala, 2001). Some of these colonies may then grow to be sufficiently strong by the next winter, but at that point would have lower mite infestation levels compared to the previous fall. Thus, some colonies in the experiment may have survived part of the time because of this dynamic host-parasite interaction. This is an important observation, because it puts anecdotal observations by beekeepers of surviving colonies in a different perspective. Survival of 
individual colonies, also for extended periods, does not necessarily mean that such bees have developed specific traits for tolerance to $V$. destructor. For the colonies in our experiment that were still alive after over six years without mite treatment it is difficult to know if survival depended on random events or on specific traits. But although the number of colonies that have survived in the present experiment is limited, the significant increase in colony survival and swarming rates and the decrease in mite infestation rates clearly indicated that the reported development was not driven primarily by fluctuating dynamics in mite and bee population sizes. The only possible conclusion that explains the experimental outcome is an adaptive process on behalf of the bees, the mites, or both. The course of $V$. destructor infestation over the years shows similarities to the development observed in a tropical island of Brazil where mite infested European bee colonies were left untreated since 1984: after an increase in the infestation levels of the adult bees during the first years the infestation decreased continuously leading to an obviously balanced relationship between host and parasite till today (de Jong and Soares, 1997; de Jong 2005, pers. comm.). Unfortunately, also in this case, the critical factors for this stable situation are unknown.

Our results allow us to conclude that the problems facing the apicultural industry with mite infestations probably is linked to the apicultural system, where beekeepers remove the selective pressure induced from the parasitism by removing mites through control efforts. Further experiments must confirm whether selection experiments as described here can be used as a basis for further honey bee breeding programs.

\section{ACKNOWLEDGEMENTS}

The dedicated efforts from beekeeper Åke Lyberg in supplying infrastructure and ground support is highly appreciated. The study had financial support from the National Board of Agriculture through the European Commission supported "National programme for support of beekeeping and sale of honey", from the "Gesellschaft der Freunde der Landesanstalt für Bienenkunde an der Univer- sität Hohenheim e.V.", and from the Swiss Beekeepers Association. All highly appreciated.

Résumé - Survie de colonies d'abeilles (Apis mellifera) infestées d'acariens (Varroa destructor) en climat nordique. Une population d'abeilles domestiques (Apis mellifera) isolée et génétiquement diverse de 150 colonies a été installée dans huit ruchers afin d'étudier si les acariens Varroa destructor pouvaient éradiquer la population hôte. Après avoir ajouté la même année entre 36 et 89 acariens par colonie, on n'est plus intervenu sur les colonies et on les a laissé essaimer à leur guise. Durant six ans on a noté les essaimages, le taux d'infestation par les acariens à l'automne et la taille de la population d'abeilles au printemps. Dans la mesure du possible, les essaims ont été capturés et utilisés pour regonfler les colonies. Nos données montrent qu'une certaine forme d'adaptation a dû avoir lieu dans le système, permettant la survie à la fois de l'hôte et du parasite. Le fait que (i) la proportion de colonies mourant durant l'hiver ait diminué significativement (Fig. 1), (ii) que l'incidence de l'essaimage se soit accru après plusieurs années (Fig. 2), et (iii) que les taux d'infestation des abeilles adultes à l'automne aient diminué (Fig. 3) corrobore fortement l'hypothèse selon laquelle le système se développe en une relation hôte-parasite où les deux parties survivent. Du point de vue de l'épidémiologie évolutive, ceci correspond à la prédiction (Fries et Camazine, 2001) à condition que la population hôte ne meure pas. Il reste à étudier si ce développement repose sur la tolérance des abeilles aux acariens, sur la moindre virulence des acariens (et des infections virales qu'ils véhiculent) ou sur les deux.

Les données récoltées suggèrent que les fortes infestations par V. destructor à l'automne peuvent être la cause de mauvais résultats d'hivernage et que les colonies qui néanmoins survivent avec un petit nombre d'abeilles puissent parfois se développer suffisamment et passer l'hiver suivant, mais avec des taux d'infestation moindres (Tabs. II, III). Certaines colonies de l'expérimentation ont pu ainsi survivre un temps en raison de cette interaction dynamique hôte-parasite. Cela n'explique pourtant pas les variations de taux dans la mortalité hivernale, les taux d'essaimage, ni les taux d'infestation. Les résultats suggèrent que le problème sur le long terme de l'apiculture avec les infestations par V. destructor est lié au système apicole, dans lequel les apiculteurs suppriment la pression de sélection induite par le parasitisme en éliminant les acariens par des traitements.

Varroa destructor / Apis mellifera / interaction hôte-parasite / survie / adaptation

Zusammenfassung - Das Überleben milbeninfizierter (Varroa destructor) Honigbienenvölker in einem nordischen Klima. Um zu untersuchen, ob 
Varroamilben (Varroa destructor) eine Wirtspopulation ausrotten können, wurde eine isolierte und genetisch diverse Bienenpopulation aus 150 Bienenvölkern auf 8 Bienenständen eingerichtet. Nach Zufügung von 36 bis 89 Milben pro Volk im Juli des gleichen Jahres konnten die unbewirtschafteten Völker nach Belieben schwärmen und wurden über einen Zeitraum von 6 Jahren auf Schwarmhäufigkeit, Milbenbefallsrate im Herbst und Bienenpopulation im Frühjahr untersucht. Soweit möglich, wurden die Schwärme eingefangen und zur Ergänzung der Population genutzt. Die vorgelegten Daten zeigen, dass in dem System eine Form von Anpassung aufgetreten sein muss, die das Überleben von Wirten und Parasiten ermöglichte. Die Tatsache, dass (i) der Anteil über Winter gestorbener Völker signifikant abnahm (Abb. 1), (ii) nach mehreren Jahren die Schwarmtätigkeit wieder zunahm (Abb. 2) und (iii) die Milbenbefallsrate der adulten Bienen im Herbst abnahm (Abb. 3), ist eine starke Unterstützung für die Hypothese, dass sich das System in Richtung einer Wirt-Parasit-Beziehung entwickelt, bei der beide Partner überleben. Aus einer evolutionären epidemiologischen Perspektive entspricht dies der Vorhersage (Fries und Camazine, 2001) unter der Vorraussetzung, dass die Wirtspopulation nicht zuvor zu Grunde geht. Ob diese Entwicklung darauf beruht, dass die Bienen milbentolerant wurden, die Milben (zusammen mit den übertragenen Viren) weniger virulent wurden oder beides, muss noch geklärt werden.

Die gesammelten Daten legen weiterhin nahe, dass ein hoher Milbenbefall im Herbst zu schlechten Überwinterungsergebnissen führt. Völker, die trotz geringer Bienenanzahlen dennoch überleben, wurden häufig über die Saison genügend stark um den nächsten Winter zu überleben, wobei sie dann einen geringeren Milbenbefall aufwiesen. Es ist daher möglich, dass einige der Völker in dem Experiment über einen Teil der Versuchszeit auf Grund dieser Dynamik in der Wirt-Parasit-Beziehung überlebt haben. Dies erklärt allerdings nicht die Änderung in der Wintermortalität, der Häufigkeit des Schwärmens oder der Milbenbefallsrate. Die Ergebnisse legen weiterhin nahe, dass das langjährige Problem der Bienenhaltung mit dem Milbenbefall vermutlich mit der Methode der Bienenhaltung zusammenhängt, bei der die Imker den von den Parasiten ausgeübten Selektionsdruck beseitigen, indem sie die Milben durch Behandlungsmaßnahmen entfernen.

Varroa destructor / Apis mellifera / Wirt-ParasitBeziehung / Überleben / Anpassung

\section{REFERENCES}

Boecking O., Ritter W. (1993) Grooming and removal behaviour of Apis mellifera intermissa in Tunesia against Varroa jacobsoni, J. Apic. Res. 32, 127134.
Deredec A., Courchamp F. (2003) Extinction thresholds in host-parasite dynamics, Ann. Zool. Fenn. 40, 115-130.

de Jong D., Soares A.E.E. (1997) An isolated population of Italian bees that has survived Varroa jacobsoni infestation without treatment for over 12 years, Am. Bee J. 137, 742-745.

Fries I., Camazine S. (2001) Implications of horizontal and vertical pathogen transmission for honey bee epidemiology, Apidologie 32, 199-214.

Fries I., Perez-Escala S. (2001) Mortality of varroa mites (Varroa destructor) in honey bee (Apis mellifera) colonies during winter, Apidologie 32, 223-229.

Fries I., Camazine S., Sneyd J. (1994) Population dynamics of Varroa jacobsoni: a model and a review, Bee World 75, 5-28.

Fries I., Wei H., Shi W., Chen S.J. (1996) Grooming behavior and damaged mites (Varroa jacobsoni) in Apis cerana cerana and Apis mellifera ligustica, Apidologie 27, 3-11.

Fries I., Hansen H., Imdorf A., Rosenkranz P. (2003) Swarming in honey bees (Apis mellifera) and Varroa mite (Varroa destructor) population development in Sweden, Apidologie 34, 1-9.

Imdorf A., Bühlmann G., Gerig L., Kilchenmann V., Wille H. (1987) Überprüfung der Schätzmethode zur Ermittlung der Brutfläche und der Anzahl Arbeiterinnen in freifliegenden Bienenvölkern, Apidologie 18, 137-146.

Kefuss J., Vanpoucke J., Ducos de Lahitte J., Ritter W. (2004) Varroa tolerance in France of intermissa bees from Tunesia and their naturally mated descendants: 1993-2004, Am. Bee J. 144, 563-568.

Korpela S., Aarhus A., Fries I., Hansen H. (1993) Varroa jacobsoni Oud. in cold climates: population growth, winter mortality and influence on survival of honey bee colonies, J. Apic. Res. 31, 157164.

Le Conte Y. (2004) Honey bees surviving Varroa destructor infestations in France, in: Experts' meeting on apiculture Varroa control, Brussels 24 October 2003, European Commission, Brussels, pp. 82-84.

Peng Y.S., Fang Y., Xu S., Ge L. (1987) The resistance mechanism of the Asian honey bee Apis cerana Fabr. to an ectoparasitic mite, Varroa jacobsoni Oudemans, J. Invertebr. Pathol. 49, 54-60.

Rath W., Drescher W. (1990) Response of Apis cerana Fabr. towards brood infested with Varroa jacobsoni Oud. and infestation rate of colonies in Thailand, Apidologie 21, 311-321.

Rosenkranz P. (1999) Honey bee (Apis mellifera L.) tolerance to Varroa jacobsoni Oud. in South America, Apidologie 30, 159-172.

Seeley T. (2004) Forest bees and Varroa mites, Bee Culture 132, 22-23. 